\title{
Exports and FDI motivations: empirical evidence from US foreign subsidiaries
}

\author{
Chiara Franco*
}

December 16, 2009

\begin{abstract}
The expected indirect benefits Foreign Direct Investments (FDI) are supposed to bring into the host countries are drawn mainly from studies at the microeconomic level. Empirical analyses examine whether FDI may be the source of productivity spillover effect on local firms and a new emerging literature analyses the effect with regard to the their export performance. However, conclusive results have not been reached so far. Two main shortcomings affect this literature: firstly, it is difficult to generalize results valid across countries; secondly, the role played by FDI motivations is largely disregarded. For these reasons, the aim of the paper is that of testing the effects of US FDI on export intensity at the sectoral level in 16 OECD countries over the period 1990-2001. Through these data, we are able to disentangle asset seeking and asset exploiting motivations and especially we are able to distinguish the channels through which the effect is going to occur. The findings show that taking into consideration the different motivations for which Multinational Enterprises (MNEs) invest abroad is relevant. The asset exploiting motivations, and in particular market seeking FDI, are those that affect export intensity to a greater extent.
\end{abstract}

Keywords: Exports, FDI motivations, spillover

JEL: F14, F21, F23

*-mail: chiara.franco2@,unibo.it
Department of Economics
University of Bologna

\section{Acknowledgments}

The author gratefully acknowledges comments and suggestions from the participants to the XI European Trade Study Group (ETSG) Conference held in Rome (Italy) (10-12 September, 2009) and EAEPE Conference held in Amsterdam (Netherlands) (6-8 November, 2009) on previous versions of the paper. 


\section{Introduction}

The growth of Multinational Enterprises (MNEs) activities through Foreign Direct Investments (FDI) in developed and developing countries has largely attracted the attention of policy makers because of the expected positive impacts they may have on receiving countries. On the one side empirical studies try to shed light on the occurrence of growth enhancing effects caused by the new available resources such as capital, technology and skills that FDI are supposed to bring into the host countries. In particular, studies focused on developing countries point to the need of reaching a threshold level of absorptive capacity to grasp FDI benefits (e.g. Borensztein et al., 1998). On the other side, a huge strand of literature deals with the same topic from a microeconomic point of view. In this case, the mechanisms described are those implied in the occurrence of the productivity spillover effects. Indeed, MNEs own superior technological and managerial capabilities that may spill over affecting the production function of local firms (Blomström and Kokko, 1998). The empirical evidence is not unanimous in finding conclusive results as they are highly dependent firstly on econometric issues such as the kind of data used to test the effect (Görg and Strobl, 2001) or the use of appropriate estimation technique (Castellani and Zanfei, 2007) and, secondly, on the heterogeneous characteristics of local firms in term of absorptive capacities or technology gap (Lipsey and Shjölm, 2005; Meyer and Sinani, 2009).

Two main drawbacks affect this type of literature: the first pertains to the narrow approach followed in the empirical analysis. It implies that the effect is searched only with respect to total factor productivity (TFP) of local firms. However, a new strand of literature is starting to account for the effects noticeable on export performance: it goes under the heading of "export spillover effect" as it acknowledges the relevance of FDI in influencing the decision to export and the export intensity of local firms (e.g. Greenaway et al., 2004). The second drawback is that both at the micro and macro level of analysis, the role played by heterogeneity on the side of MNEs is usually disregarded. Indeed, FDI are treated as homogeneous entities able to produce the same outcome everywhere. Even though a debate is open on the issue of subsidiaries heterogeneity (e.g. Cantwell and Mudambi, 2005), not enough effort has been carried out to understand how MNEs may differ in their ability to affect host locations. The approach we follow is that of taking into consideration FDI motivations by moving from the Dunning's (1993) taxonomy that separates asset seeking from asset exploiting motivations. Only a few papers, however, has succeeded in examining the impact that different FDI motivations cause on the host countries. An attempt comes from the paper by Beugelsdijk et al. (2008) who show that in developed countries horizontal FDI contribute more to GDP growth than vertical FDI. 
Driffield and Love (2007) by testing the impact of FDI on productivity of domestic firms, find that UK gains only from FDI with asset exploiting motivations while asset seeking FDI lead to non significant results.

It is also worth noting that studies examining productivity spillover effect are essentially case studies focused on single countries ${ }^{1}$. Even though with a few exceptions (e.g. Bitzer et al., 2008), no comparative analyses have been carried out so far and, for this reason, it is not easy to generalize results across countries.

To tackle these shortcomings, we make an effort to put together the two emerging strands of literature of FDI export spillover effect and that of FDI motivations that, at present, are evolving quite independently. In particular, the aim of the paper is that of analyzing at the sectoral level the empirical relationship occurring between different FDI motivations and export intensity over the period 19902001. Data coming from the Bureau of Economic Analysis (BEA) provide informations about the activities of US foreign affiliates in 16 OECD host countries, through which we can distinguish between asset exploiting and asset seeking motivations.

The paper is structured as follows: the second section reviews the literature dealing with the topic of the impact of FDI on host countries. Section 3 theoretically discusses why FDI motivations are an important aspect to clarify the final effect on export intensity and proposes a set of testable hypotheses. The fourth section describes the data and the empirical approach followed; the fifth section provides some comments to results and section 6 concludes.

\section{The impact of FDI on host countries}

The first theoretical strand of literature on which this paper is based deals with the likely impacts that MNEs may have on host countries where they decide to invest through FDI. With respect to the macroeconomic side of the analysis, the research question focus on the impact of FDI on aggregate growth of the host country. Empirical studies usually test the impact on a developing context identifying two main issues: the first highlights the problem of endogeneity between FDI and growth (e.g. Li and Liu, 2005; Duttaray et al., 2008) according to which it results quite difficult to investigate the direction of causality between the two variables at stake. The second issue concerns the role played by mediating factors in influencing the final effect. For example, Borensztein et al. (1998) who analyze the case of 69 developing countries, find that the effect of FDI on host countries is positive only when coupled with a suitable level of human capital. A similar point is supported by Alfaro et al. (2004) who recognize how a well developed financial system is relevant for a positive effect to occur. In the same way, Olofsdotter (1998) justifies the positive results found by arguing that only countries with high quality institutions, especially in terms of burocratic efficiency and strength of patent rights, are in the

\footnotetext{
${ }^{1}$ This is true even for the new strand of literature analyzing the export spillover effect.
} 
position to absorb knowledge coming from foreign sources. However, negative results are found as well: Bende-Nende et al. (2003) observe negative effects in Japan and Taiwan despite the relevant technological capabilities accumulated by those countries.

The same ambiguity in empirical results applies for microeconomic studies. Their aim is that of investigating how TFP of local firms is affected by MNE's activities. A large stream of literature has grown around the concept of productivity spillover whose definition mainly overlaps with the concept of externality (Blomström and Kokko, 1998). Its theoretical underpinnings can be found in the Ownership, Location and Internalisation (OLI) paradigm (Dunning, 1977) ${ }^{2}$ according to which MNEs display a higher economic performance than local firms as they are endowed with superior technological, managerial and marketing skills that may spillover through different channels. However, two different sets of motivations are responsible for blurred results coming from the empirical literature. The first refers to the econometric methods used to test the presence of such effects. This aspect is examined in the meta analysis by Görg and Strobl (2001) who observe that, usually, studies making use of cross sectional data rather than panel data systematically overestimate spillovers. In the same way, Castellani and Zanfei (2007) support the possibility of the occurrence of a specification error in the way the externality term is measured.

On the other side, Lipsey and Sjöholm (2005) think that, even though there may be problems with the use of different econometric methodologies, the major differences should be detected in the insufficient absorptive capacities of local firms due to the technological backwardness at the country level. This point is acknowledged by the meta analysis carried out by Meyer and Sinani (2009) whose results show that productivity spillovers display a $U$ shaped relationship with per capita income, human capital and institutional development while a positive linear relationship is found with regard to trade openness.

The spillover effect may occur both through intraindustry channels, that is between MNEs and local firms operating in the same sector, and through interindustry channels, that is between MNEs and local firms belonging to two different sectors. Empirical literature especially relative to developing and transition countries, detects a positive effect especially with regard to interindustry rather than intraindustry channels in this way pointing out that backward and forward linkages may result the most suitable means of technology transfer (Javorcik, 2004; Kugler, 2006). Indeed, MNEs may be more willing to share their technological knowledge with suppliers rather than with competitors as they are interested in being supplied with high quality standard products.

The relevance given to the investigation of FDI impact on other variables, such as exports, is rather weak. However, some studies have recently started to examine how the presence of FDI may

\footnotetext{
2 The theoretical framework put forward by Dunning (1977) analyses the conditions according to which a firm decides to engage in FDI in comparison to other means of investing abroad. The advantages that FDI provide are based on the ownership of firm specific technological or managerial assets $(\mathrm{O})$ that are exploited in a specific favourable location (L) inside the same firm (I).
} 
influence export performance of local firms. As in the case of productivity spillovers, conflicting results have been found. The first study on this topic is by Aitken et al. (1997) who examine the case of Mexico over the period 1986-1990, finding positive results with regard to the impact of MNEs on the probability of domestic firms to enter into the export market. The same methodology is followed by Kokko et al. (2001) who explore the case of Uruguay in 1988. They are the first to account for possible heterogeneity in MNEs behaviour splitting the sample in two time periods, before and after 1973, as, since that year, a more liberalized and outward oriented regime was adopted in that country. In line with expectations, the empirical findings point to a positive effect on export decision of local firms coming from MNEs established after 1973, because their export spillover potential was higher. A different approach has been followed by successive studies that separate the effect FDI have on the decision to export and, provided that the firm has decided to export, on the export intensity. For example, Greenaway et al. (2004) analyse how MNEs' presence inside UK over the period 1992-1996 influences local firms export performance. In particular, they explore the relationship by trying to disentangle the different channels through which the effect is going to occur. The competition effect implies that the presence of FDI may entail a process by which local firms in order not to be pushed out of the market improve their productivity and, as a consequence, their export performance. The imitation channel reports the effect caused by the exposure of local firms to the MNEs' R\&D activities. The last channel singled out, namely the demonstration effect, describes the role played by MNEs' exports in lowering the sunk costs of exporting activities of local firms, as it implies the exchange of higher informations MNEs have due to their involvement in foreign markets. They observe positive effects especially with regard to competition and imitation channels both for export decision and export intensity. Contrary to this study, but further disentangling intraindustry from interindustry channels, are the findings by Kneller and Pisu (2007) examining UK for the time span 1992-1999. They observe that intraindustry channels do not affect export decision, while export intensity is positively influenced by both intraindustry and interindustry channels. Instead, Barrios et al. (2003) considering the case of Spain in the period 1990-1998 show that only imitation effect has some relevance in influencing the export performance of local firms. Ruane and Sutherland (2005) find even negative results for Ireland; they are attributed to the export platform motivation according to which MNEs are attracted in that country. This paper is particularly relevant to our discussion as it calls into question the FDI motivation issue, even though they do not explicitly use proxies to measure the effect of this motivation but they simply inferred it ex-post.

To sum up, the most relevant drawback of these studies is that of disregarding the heterogeneity on the side of MNEs: it means that usually FDI are considered as homogeneous exogenous factors not taking into account that motivations for which MNEs invest in a foreign country may affect the spillover potential. Moreover, it should be noted that all these microeconomic studies 
are usually focused upon one single host country without the possibility of generalizing results across countries. Only two exceptions, even though not related to export spillover effect, are present in the literature. The first is by Damijan et al. (2003) who search for productivity spillover effect using firm level data for ten transition countries and the second is by Bitzer et al. (2008) who investigate the relationship between FDI and productivity spillover, at the sectoral level, in 17 OECD countries. They both find positive results occurring through interindustry channels.

\section{FDI motivations and their effects in the host countries}

FDI motivations have been analyzed mainly at a theoretical level with scarce studies searching for the possible impacts that different types of FDI may have on receiving countries. Indeed, the literature about spillover effect does not properly take into consideration the real motivations according to which MNEs invest in a foreign country. Theoretical literature deals with the topic of FDI motivation both through the use of formal models of international trade and the use of an international business approach. As a matter of fact two different classifications of FDI motivations have been put forward: the first, following the former approach, entails the difference between horizontal and vertical FDI. The early models describing these types of investment are those by Helpman (1984) and Markusen (1984). In the first case, MNEs invest in a foreign country to avoid transportation costs or to skip trade protection mechanisms that are in place in the host country ${ }^{3}$, while, in the second case, the aim is that of moving part of the production chain abroad in order to take advantage of lower labour costs $^{4}$. By employing this theoretical framework, Beugelsdijk et al. (2008) distinguish between the effect of vertical and horizontal FDI on the overall level of growth of receiving countries. They find that developed countries are positively influenced especially by horizontal FDI rather than by vertical FDI. They motivate this result by proposing the theoretical argument according to which, as Lall (1980) points out, effects are greater if MNEs are more embedded inside the local context because of the higher possibilities to interact with local firms. Instead, as investigated in the paper by Kokko (1994), MNEs that invest in the so called "enclave" industries ${ }^{5}$ are not deemed to produce positive spillover effects. According to the international business literature, these two motivations go both under the heading of asset exploiting motivations. These are based upon the theoretical idea for which MNEs invest abroad because they have superior firm specific technological assets that it is most favourable to exploit in foreign locations through a new investment with respect to other means of foreign

\footnotetext{
${ }^{3}$ These are also known as tariff-jumping FDI.

${ }_{4}^{4}$ These two basic models have been lately modified to propose that both motivations may be present at once as in the knowledge capital model, (Markusen and Maskus, 2002) and that the value chain may be split in more than two stages (Grossman et al., 2006).

5 They are characterized by large technology gap between MNEs and local firms and by the low share of local firms with respect to foreign firms.
} 
penetration, such as exports or licensing (Dunning, 1979). According to the taxonomy put forward by Dunning (1993), mainly three asset exploiting categories have been singled out: market seeking, resource seeking and efficiency seeking. The latter category is usually considered in the empirical literature to overlap with resource seeking strategy, that is to take advantage of low cost resources or of resources that are not available in the home country. Instead, market seeking FDI occur when MNEs invest in a foreign country in order to exploit a market of greater dimension than the one in the home country. A particular case of market seeking FDI is the export platform FDI whose aim is not that of exploiting the larger host country market, but rather that of using it as a platform to export in third countries $^{6}$. One of the first study that reports the existence of export platform FDI is by Hanson, Mataloni and Slaughter (2005). By using data on the foreign operations of US multinationals they find there has been an increase of FDI flows in Mexico and Canada after the formation of North American Free Trade Agreement (NAFTA) even though the average share of exports to affiliate has remained the same $^{7}$. It is important to explicit that market seeking and resource seeking FDI mainly overlap respectively with horizontal and vertical FDI as defined in the international trade approach.

Besides the asset exploiting motivations, following the Dunning's categorization we take into consideration also the role of strategic asset seeking FDI: this motivation is supported by studies indicating that in specific circumstances, MNEs' aim is not confined to the exploitation of a preexistent ownership advantage but, instead, they search for other assets that complement their technological base (Kuemmerle, 1999; Le Bas and Sierra, 2002). Actually, as claimed by Fosfuri and Motta (1999) even laggard firms may engage in FDI because of the higher return available if they are able to grasp possible localized knowledge spillover effect. This effect is confirmed by studies providing evidence of the growing phenomenon of R\&D internationalization (e.g. Kumar, 2001) for which the willingness of MNEs to locate R\&D facilities abroad is not simply due to the need of adapting the product to local market needs (R\&D exploiting motivations) but also of augmenting national innovation capacities through reverse knowledge transfer from local firms to MNEs.

Very few papers, test the impact of FDI motivations referring to the theoretical framework of Dunning's (1993) taxonomy. In this respect, Driffield and Love (2007) account for the productivity spillover effect by putting forward a taxonomy in which they are disentangled asset exploiting and asset seeking motivations focusing on both technology and factor costs differentials to explain FDI flows. With regard to the case of UK, examined over the period 1987-1997, they do not find that asset seeking FDI cause the occurrence of a positive spillover effect as they do not bring superior technological assets into the host country. Instead, authors find that UK gains mostly from FDI motivated by the exploitation of a specific technological advantage.

\footnotetext{
${ }^{6}$ Usually, the export market exploited is the one that shares a border with the host country in which the production base is located.

${ }^{7}$ Recent evidence proving the existence of this motivation for FDI has been provided by Ekholm et al. (2007).
} 
In the literature discussed above, some issues are not included in the analysis: firstly, at the country level they are only tested the different effects caused by horizontal and vertical FDI without considering that even export platform FDI may impact on the economic structure of the host countries. Secondly, spillover effects are examined by looking at the level of growth or the TFP of domestic firms, while it is not investigated the role FDI may have on the international competitiveness of the country. This effect may also be biased according to which sectors are considered.

\subsection{Testable Hypotheses}

The empirical analysis we are going to carry out involves two stages: in the first, following the Dunning's (1993) taxonomy we measure the impact of FDI using proxies for the three asset exploiting motivations he singles out, namely market seeking, resource seeking and export platform FDI. However, due to the peculiar characteristics of the home and host countries and of the sectors analyzed we think that in the second stage of the analysis we need to disentangle the channels through which the effect is going to occur. In this way, we are able to differentiate between asset seeking and asset exploiting motivations.

For this reason, with regard to the first stage of our analysis, we discuss some broad theoretical hypotheses that may guide the interpretations of results (Table 1): the first is that in the case of market seeking FDI, the effect on exports will be first mediated by the ability of firms to remain on the market because of the higher competition established after MNE's investment, thus enhancing their productivity. If, instead, some firms are pushed out of the market, the overall productivity of the sector shrinks and, as a consequence, the export intensity diminishes. However, market seeking FDI involve a higher level of embeddedness inside the host context in this way reinforcing contacts between MNEs and local firms and thus inducing a greater spillover potential. Nevertheless, they are also those that are less involved in foreign markets, because, by definition, they mainly have a domestic market orientation. For these reasons, a non significant result is expected. With regard to resource seeking FDI, the predicted effect may be positive for two reasons: even though the level of embeddedness of the subsidiaries does not reach the level of market seeking FDI they may have a positive impact because they should increase the local labour demand. Moreover, this type of FDI provides a greater demonstration effect because of the greater MNEs' engagement in trade networks, both inside export and import markets. Finally, even in the case of export platform, different mechanisms are at work: the first is that, as pointed out by Ruane and Southerland (2005), the level of linkages with firms is low and, for this reason, the level of knowledge transfer may be lower as well. However, on the other side, the higher demonstration effects provided by MNEs that are even more export oriented than resource seeking FDI, should cause a decrease in the sunk costs of local firms positively affecting the local sectoral export performance. Nevertheless, it may also happen that MNEs and local firms become 
competitors if they export in the same foreign markets. For this reason, export platform FDI may cause an overall negative effect on the sectoral export intensity.

These are only general expectations that still represent an aggregate point of view. Actually, in the second stage of the analysis, by further disentangling the way through which the spillover effect occurs a clearer picture emerges. In particular, we are able to do so by distinguishing among four different channels. Two of them, R\&D and skills, highlight MNEs' technological activities. Through imitation effect, they should spur higher export performance even though this effect is expected only when considering the case of market seeking FDI. The reason is that firms in OECD countries should be able to successfully imitate technologies. In particular, by drawing from the strand of literature that analyses the phenomenon of R\&D delocalization (e.g. Kumar, 2001; Hedge and Hicks, 2008), it is possible to reclassify our market seeking motivations as $R \& D$ adaptive investments. It means, that if the real aim of the MNEs is that of exploiting a market of larger dimensions, the type of R\&D carried out in that country will be done for adaptive purposes. Instead, as far as resource seeking and export platform FDI are considered, the real MNEs aim is not that of exploiting natural resources or cheap labour as it may happen in the case of developing countries, but rather it is that of seeking technological resources. For this reason, as we are dealing with FDI flows between technologically developed countries we consider those types of FDI belonging to the category of asset seeking motivations. The expected effect is non significant as the purpose of those FDI is simply that of taking advantage of local available knowledge.

Similar reasons may be put forward when considering the channel relative to skills. With regard to market seeking FDI, higher worker's skills may spillover to the local sector in this way enhancing the overall level of skills of local firms. It should cause rising export intensity. Instead, for resource seeking or export platform FDI, higher skills are used by MNEs to better elaborate and incorporate into the production process the stock of knowledge with which they come in contact. As before, the expected impact is non significant.

The other two channels represent more productive oriented activities carried out by MNEs in the host country. In particular, through the channel of value added ${ }^{8}$ it is possible to take into account whether the degree of embeddedness inside the host country positively influence export performance of the domestic sector. As a matter of fact the importance of local production activities carried out in the host country may significantly affect technological development and, in turn, export performance. The expectations for market seeking FDI are positive as higher embeddness may favour the occurrence of the spillover effect because of the higher level of linkages established with the domestic sector. This is also a way to measure the "true" asset exploiting motivations with respect to resource and export platform FDI as in the case of $R \& D$ and skills channels we accounted just for asset seeking

\footnotetext{
${ }^{8}$ The variables measuring value added and capital expenditures are available only from 1994 onwards.
} 
motivations. By doing this we are actually able to compare which of the asset seeking motivations is more effective in transmitting the export spillover effect. We should expect a positive even though mild effect coming from resource seeking FDI as more embedded FDI are going to have higher labour creating effect that in turn should increase exports. However, as we are considering FDI flows between developed countries, it is possible that a mismatch of the workers' skills needed in foreign subsidiaries and available in the local market may occur. For this reason, a non significant result may also occur. As far as export platform FDI are concerned, the effect is expected to be non significant as, even though the level of embeddedness may grow over time it will not be able to reach the same degree of market seeking and resource seeking FDI.

As a further way to account for the difference among asset exploiting motivations in impacting on export performance, we consider the competition channel. The expectations are that of a positive effect coming from market seeking FDI because of their superior domestic market orientation they should spur competition inside the host country. As we are dealing with developed receiving countries, firms should be able to positively respond to competition by increasing their productivity and consequently increasing export performance. This effect, should be positive also for resource seeking FDI while it should be an irrelevant channel for export platform FDI whose sales are not directed to the domestic market leaving the competition level unchanged.

Table 1. Expected effect of FDI motivations channels

\begin{tabular}{|l|l|}
\hline FDI motivation & Expected effect \\
\hline Market seeking & $==$ \\
\hline Resource seeking & + \\
\hline Export platform & + \\
\hline Market seeking*R\&D (AE) & + \\
\hline Market seeking*skills (AE) & + \\
\hline Market seeking*added value (AE) & + \\
\hline Market seeking*capital expenditures (AE) & $==$ \\
\hline Resource seeking*R\&D (AS) & $==$ \\
\hline Resource seeking*skills (AS) & $+/==$ \\
\hline Resource seeking*added value (AE) & + \\
\hline Resource seeking*capital expenditures (AE) & + \\
\hline Export platform*R\&D (AS) & $==$ \\
\hline Export platform*skills (AS) & $==$ \\
\hline Export platform*added value (AE) & $==$ \\
\hline Export platform*capital expenditures (AE) & $=$ \\
\hline
\end{tabular}

Note: AE indicates Asset Exploiting motivation; AS indicates Asset seeking motivation 


\section{Dataset and Empirical Approach}

This study is quite different from the similar export spillover studies carried out so far. In the first place, we do not use a two step modelling strategy following the Heckman selection model (Heckman, 1979) like in the case of firm level studies. Instead, due to the use of sectoral level data only the final effect on export intensity can be investigated. In the second place, we examine the relationship between outward FDI from just one home country (the US) towards 16 OECD $^{9}$ developed countries over the period 1990-2001. We clarify that only the possible occurrence of horizontal export spillover effect is tested (intraindustry channel). To this aim, two different datasets have been combined: the first is made up of data on US multinationals and operations of their foreign affiliate abroad ${ }^{10}$, derived from the United States Bureau of Economic Analysis (BEA). By using these data disaggregated at the sectoral level it is possible to single out proxies for three different types of FDI motivations. We distinguish between market seeking FDI $\left(\mathrm{Mseek}_{\mathrm{ijt}}\right)^{11}$ measured as the amount of sales in the host country in which the investment is carried out; resource seeking FDI (Rseek $\mathrm{k}_{\mathrm{ijt}}$ ) that are measures by the amount of sales back to the US and, in the end, export platform FDI (Expplat $\mathrm{i}_{\mathrm{ijt}}$ ), measured by the amount of sales to foreign countries other than the host country. All these variables are included into the model as shares to total sales and they are all deflated using industry level GDP deflators.

The second dataset comes from the STAN indicators $\left(2005\right.$ edition ${ }^{12}:$ it contains more than 30 measures about international trade, industrial composition, business enterprise R\&D, employment, productivity and investment. For the present analysis we choose the indicators useful to account for sectoral exports determinants.

The dependent variable is the sectoral export intensity $\left(\mathrm{XPROD}_{i j t}\right)$ measured as the export share of production. To account for the fact that exports intensity may show persistence in time it is added as depended variable the value lagged one year. In order to explain the increase or decrease of export intensity at the sectoral level, some other sectoral level variables are added to the specification. In the first place, following the literature claiming the importance of technological export determinants (e.g. Power, 1998) we use R\&D intensity $\left(\operatorname{RDPROD}_{i j t}\right)$ as well as a proxy to measure worker's skills $\left(\right.$ LABEMP $\left._{j i t}\right)$ built using labour compensation per employee relative to labor compensation per employee of total economy. Especially in developed countries, more capital intensive sectors should export more. For this reason, by using investment intensity measured as the ratio of gross fixed capital formation to value added (INVINT $T_{i j t}$ ) we account for this further determinant. Moreover, we recognize

\footnotetext{
${ }^{9}$ Countries are: Australia, Belgium, Canada, Denmark, Finland, France, Germany, Ireland, Italy, Japan, South Korea, Netherlands, Norway, Spain, Sweden, United Kingdom.

${ }^{10}$ We consider data only with respect to majority owned subsidiaries.

11 i represents country, $j$ sector and $t$ the year.

12 These indicators are calculated by using STAN Database for Industrial Analysis (STAN) for variables related to output, investment, trade and the data coming from Analytical Business Enterprise (ANBERD) as far as R\&D data are concerned.
} 
the need to control for sectoral productivity as we expect that higher productivity will lead to higher export intensity. This effect is measured using labour productivity (LPDTY ${ }_{i j t}$ ), built as the ratio of value added volumes to the number of employees engaged. In the end, a couple of variables should account for the structure of the economy: the first is the size of each sector on the size of the total economy that is measured using the share of each industry's employment to employment of the total economy $\left(\mathrm{EMPSH}_{i j t}\right)$. It takes into account that the larger the size of the sector, the more market oriented it is and, for this reason, firms will be more oriented to serve local demand rather than operating in foreign markets. The second variable used is the composition of total exports $\left(\mathrm{XSH}_{i j t}\right)$. This variable is used to represent the share each sector's has on total exports of the country. It accounts for the possibility that MNEs may choose to locate in higher export oriented sectors.

The present analysis is confined to those sectors, namely machinery, chemicals and transport equipment (ISIC Rev. 3 division), that according to OECD definitions are considered as medium high technology manufactures. The focus on these sectors allow us to better capture both asset seeking and asset exploiting motivations, rather than focusing only on low tech sectors that usually are the target just for asset exploiting FDI. Furthermore, as outward FDI country and inward FDI receiving countries are both developed countries, a higher share of FDI is concentrated in more technology intensive sectors.

The analysis is carried in two steps: the first baseline specification simply tests how the three different FDI motivations impact on the export intensity of domestic sectors. However, to avoid possible multicollinearity problems (see correlation matrix Table A1, Appendix) and to separate the three effects, just one variable is used in each model. It means that FDI variable in each equation is replaced by market seeking, resource seeking and export platform FDI motivations In this way, three different baseline models are estimated. Time dummies are involved into the model to take into account possible time invariant factors and business cycles effects.

$$
\begin{aligned}
& \mathrm{XPROD}_{j j t}=\alpha+\beta_{1} \mathrm{XPROD}_{j j t-1}+\beta_{2} \mathrm{FDI}_{j j t}+\beta_{3} \mathrm{INVINT}_{i j t}+\beta_{4} \mathrm{RDPROD}_{j j t}+\beta_{5} \mathrm{LABEMP}_{i j t}+ \\
& \beta_{6} \mathrm{LPDTY}_{i j t}+\beta_{7} \mathrm{EMPSH}_{j j t}+\beta_{8} \mathrm{XSH}_{i j t}+\text { Time dummies }+v_{i}
\end{aligned}
$$

The endogeneity issues caused by the presence of the FDI variable and the lagged export intensity need to be addressed by suitable econometric methodology. It is possible to tackle this issue through several methods such as by lagging the suspected endogenous variables or by using a two stage least square method inside the framework of a gravity equation. However, the task of finding instrumental variables at the sectoral level is not easy. For this reason, the empirical analyses are carried out using Generalized Methods of Moment (GMM) estimators. This estimation method may be applied in two ways: using difference GMM (diff-GMM), which employs lagged levels as instruments for first- 
differenced equation, or using system GMM (sys-GMM). As shown by Arellano and Bover (1995), the difference GMM technique may have problems with weak instruments due to the presence of lagged level instruments. Instead, Arellano and Bond (1991) and Blundell and Bond (1999) suggest that an application of the system GMM estimators is a more appropriate approach to dynamic panel data than using the diff-GMM estimators because of greater efficiency. We used as instruments for the suspected endogenous variables, the second lag of those variables: in particular, earlier instruments dated t-2 for the equations in first differences and instruments dated $t-1$ for the equations in level ${ }^{13}$. We report robust standard errors to correct for possible heteroschedasticity; finally, as Madariaga and Poncet (2007) sustain, in order not to have biased estimates as our sample is not large ${ }^{14}$, we use one step estimator instead of two step even though it would be more efficient to use the latter.

The second specification aims at further disentangling the different channels trough which the effect may occur. However, as already explained, the further aim involved in this exercise is that of taking into consideration that, due to the characteristics of home and host countries inside asset exploiting motivations may be found even asset seeking motivations. Each of the three variables built before are interacted with $\mathrm{R} \& \mathrm{D}$, a measures of affiliate's skills (compensation of employees divided by the number of employees) value added and capital expenditure. $\mathrm{XPROD}_{i j t}=\alpha+\beta_{1} \mathrm{XPROD}_{i j t-1}+\beta_{2} \mathrm{FDI}_{i j t} * \mathrm{RD}_{i j t}+\beta_{3} \mathrm{INVINT}_{i j t}+\beta_{4} \mathrm{RDPROD}_{i j t}+\beta_{5} \mathrm{LABEMP}_{i j t}+$
$\beta_{6} \mathrm{LPDTY}_{i j t}+\beta_{7} \mathrm{EMPSH}_{i j t}+\beta_{8} \mathrm{XSH}_{i j t}+$ Time dummies $+v_{i}$

$\mathrm{XPROD}_{i j t}=\alpha+\beta_{1} \mathrm{XPROD}_{i j t-1}+\beta_{2} \mathrm{FDI}_{i j t} *$ Skills $_{j t}+\beta_{3} \mathrm{INVINT}_{j j t}+\beta_{4} \mathrm{RDPROD}_{i j t}+\beta_{5} \mathrm{LABEMP}_{j i t}+$ $\beta_{6} \mathrm{LPDTY}_{i j t}+\beta_{7} \mathrm{EMPSH}_{i j t}+\beta_{8} \mathrm{XSH}_{i j t}+$ Time dummies $+v_{i}$

$\mathrm{XPROD}_{i j t}=\alpha+\beta_{1} \mathrm{XPROD}_{i j t-1}+\beta_{2} \mathrm{FDI}_{j j t} * \operatorname{Vad}_{j j t}+\beta_{3} \mathrm{INVINT}_{i j t}+\beta_{4} \mathrm{RDPROD}_{j j t}+\beta_{5} \mathrm{LABEMP}_{j j t}+$ $\beta_{6} \mathrm{LPDTY}_{i j t}+\beta_{7} \mathrm{EMPSH}_{i j t}+\beta_{8} \mathrm{XSH}_{i j t}+$ Time dummies $+v_{\mathrm{i}}$

$\mathrm{XPROD}_{i j t}=\alpha+\beta_{1} \mathrm{XPROD}_{i j t-1}+\beta_{2} \mathrm{FDI}_{i j t} * \mathrm{Cap}_{i j t}+\beta_{3} \mathrm{INVINT}_{i j t}+\beta_{4} \mathrm{RDPROD}_{i j t}+\beta_{5} \mathrm{LABEMP}_{i j t}+$ $\beta_{6} \mathrm{LPDTY}_{i j t}+\beta_{7} \mathrm{EMPSH}_{i j t}+\beta_{8} \mathrm{XSH}_{i j t}+$ Time dummies $+v_{\mathrm{i}}$

As an extension of our model and as a further way to take into account the heterogeneous behaviour of subsidiaries, we put forward the idea that each FDI motivation may be influenced in the likely effects it is going to produce, by a different degree of linkages the subsidiaries have with the parent company. The aim is that of accounting for the more flexible approach followed by recent literature accounting for the effects coming from only those subsidiaries that are more technologically active (e.g. Marin and

\footnotetext{
${ }^{13}$ Due to problems related to the fact that the Hansen test may not be reliable when the number of instruments exceeds the number of regressors, instruments are collapsed and it is limited the use of lags $(2,3)$ for variables used as instruments (Roodman, 2006).

14 The panel is unbalanced due to missing values both for OECD and BEA datasets.
} 
Bell, 2006). Using an equivalent terminology, Cantwell and Mudambi (2005) identify them as "competence creating" subsidiaries. In particular, empirical studies found that these types of FDI are more able to foster technology transfer as their spillover potential is higher. This is true especially in the case of developing countries (e.g. Marin and Sasidharan, 2008) but this is confirmed even for developed countries such as Sweden (Holm et al., 2003). This is a bit different approach from the one proposed by the FDI motivation literature as a subsidiary driven perspective is used instead of a centrally driven perspective in which foreign subsidiaries are considered as purely technological container of assets transferred by the headquarters. However, in both types of literature none has actually contributed to make explicit the impact caused by the flow of resources coming from the network in which the subsidiary is involved. This is made up of linkages both with the parent company and other foreign subsidiaries with which it may have trade relationships. Drawing from this theoretical framework, we think that the effect each FDI motivation is going to have to stimulate the export performance of the host context may be altered by the linkages they have with the parent company and with other foreign subsidiaries. This is a novel way to account for the importance of the network of which subsidiaries are part, even though due to data constraints we have to confine ourselves to the examination of the amount of imports coming from the parent company (IMPUSP $P_{j i j}$ ).

$\mathrm{XPROD}_{i j t}=\alpha+\beta_{1} \mathrm{XPROD}_{i j t-1}+\beta_{2} \mathrm{FDI}_{i j t} * \mathrm{IMPUSP}_{i j t}+\beta_{3} \mathrm{INVINT}_{i j t}+\beta_{4} \mathrm{RDPROD}_{i j t}+\beta_{5} \mathrm{LABEMP}_{i j t}+$ $\beta_{6} \mathrm{LPDTY}_{i j t}+\beta_{7} \mathrm{EMPSH}_{i j t}+\beta_{8} \mathrm{XSH}_{j j t}+$ Time dummies $+v_{i}$

\section{Econometric results}

Table 2 presents the results for the estimation of the benchmark models. In all specifications the Hansen test is never significant indicating that the instruments chosen for endogeneous variables are valid. Moreover, as expected because of the presence of a lagged variable, it is found that there is autocorrelation of the first order while no correlation is found for second order. It confirms that the use of the sys-GMM estimation technique is reliable.

With respect to sectoral variables, by first looking at the correlation matrix it is possible to note that technological variables are expected not to play a key role. As a matter of fact, labour productivity is even negatively correlated in the case of the market seeking specification. Instead, as expected, the size of the sector is negatively correlated with the export intensity even though the coefficient is not significant. It means that a larger sector will produce more for the domestic market and less for foreign markets. The same is observed for the $\mathrm{R} \& \mathrm{D}$ variable that is not found to be significant in any specifications even though mainly with positive signs. This unexpected result shows how technological variables are not relevant even though we are examining the case of medium - hightech sectors. 
(1)

\begin{tabular}{|c|c|c|c|}
\hline xprod & $\begin{array}{l}1.04525^{* * *} \\
(0.12166)\end{array}$ & $\begin{array}{l}0.89357 * * * \\
(0.16382)\end{array}$ & $\begin{array}{l}1.07305^{* * *} \\
(0.16171)\end{array}$ \\
\hline mseek & $\begin{array}{l}43.21130^{* * *} \\
(16.14527)\end{array}$ & & \\
\hline rseek & & $\begin{array}{l}-58.85715 \\
(55.03325)\end{array}$ & \\
\hline expplat & & & $\begin{array}{l}-30.81154^{* *} \\
(15.46854)\end{array}$ \\
\hline INVINT & $\begin{array}{l}-0.11243 \\
(0.13723)\end{array}$ & $\begin{array}{l}-0.35469 \\
(0.47084)\end{array}$ & $\begin{array}{l}0.13301 \\
(0.16623)\end{array}$ \\
\hline RDPROD & $\begin{array}{l}-0.63722 \\
(0.44093)\end{array}$ & $\begin{array}{l}-1.11224 \\
(1.16311)\end{array}$ & $\begin{array}{l}0.04570 \\
(0.45462)\end{array}$ \\
\hline LABEMP & $\begin{array}{l}-0.03964 \\
(0.04060)\end{array}$ & $\begin{array}{l}-0.07018 \\
(0.07828)\end{array}$ & $\begin{array}{l}0.01278 \\
(0.03333)\end{array}$ \\
\hline LPDTY & $\begin{array}{l}-0.21099^{*} \\
(0.11314)\end{array}$ & $\begin{array}{l}-0.15762 \\
(0.16267)\end{array}$ & $\begin{array}{l}-0.12115^{*} \\
(0.07156)\end{array}$ \\
\hline EMPSH & $\begin{array}{l}-1.29784 \\
(1.97092)\end{array}$ & $\begin{array}{l}-7.67674 \\
(7.58229)\end{array}$ & $\begin{array}{l}2.33155 \\
(3.58463)\end{array}$ \\
\hline $\mathrm{XSH}$ & $\begin{array}{l}0.52071 * \\
(0.30358)\end{array}$ & $\begin{array}{l}0.81897 \\
(1.03083)\end{array}$ & $\begin{array}{l}-0.00328 \\
(0.42762)\end{array}$ \\
\hline Year dummies & Yes & Yes & Yes \\
\hline Obs. & 239 & 239 & 239 \\
\hline Wald test & 957.50 & 1283.54 & 579.65 \\
\hline AR1 & $-3.02 * * *$ & $-2.88 * * *$ & $-2.98 * * *$ \\
\hline AR2 & -1.24 & -0.76 & -0.69 \\
\hline Hansen test & 2.27 & 3.44 & 3.64 \\
\hline
\end{tabular}

Notes: xprod is lagged one year

Robust standard errors in parentheses

* significant at 10\%; ** significant at 5\%; *** significant at 1\%

Instead, we note that the lagged value of export intensity is always positive and highly significant proving that exporting activities display a certain degree of persistence. With regard to MNEs variables, we have to notice that market seeking FDI are those that to a greater extent affect the exports of the host country. It means that domestic firms are able to counterbalance the likely negative effects coming from low export orientation of these types of FDI with the positive effects coming from the higher linkages that it is possible to establish with subsidiaries. It may also reflect that firms are able to survive to competition favouring the increase in export intensity. However, at this stage of the analysis, we are not able to clearly single out which channel is responsible for such positive effect. Instead, export platform FDI are those that negatively affect the export performance of the domestic sector. It is quite counterintuitive as export platform FDI are those that to a greater extent should foster the occurrence of information externalities, contributing to lower sunk costs. However, it means that in developed countries firms already have enough linkages with the foreign markets that allow them not to suffer from high sunk costs and, for this reason, FDI and exports from OECD countries may become competitors in foreign markets. A non significant result is found for resource seeking FDI 
indicating that the expected greater impact of more export oriented FDI is not relevant as local firms, instead, need to be helped to improve first their productivity and their technological performances that, in turn, should spur even their export intensity. Secondy, it may also prove that the effect on local labour demand is negligible and does not significantly affect sectoral productivity because, at least from an aggregate point of view, subsidiaries established with the motivation of splitting up the value chain act quite detached from the local context in which they operate. Nevertheless, in this first stage of the analysis, it is not possible to disentangle the different channels through which the effects become effective and, as a consequence, it is not possible to clearly distinguish between asset seeking and asset exploiting motivations. Results relative to this distinction are presented in Tables 3 and 4. Considering first the results coming from the interaction with $R \& D$ and skills, we notice that also in this case the Hansen test indicates that instruments are reliable as it can not reject the null hypothesis that the instruments are uncorrelated with the error term ${ }^{15}$. Furthermore, we recognize that error term are first order but not second order serially correlated. As far as the market seeking FDI are concerned, as shown by coefficients, the most interesting result is that $\mathrm{R} \& \mathrm{D}$ channel does not act as a mean of export spillover effect but negatively affects it. According to the theoretical discussion of the previous sections, R\&D adaptive FDI should cause the occurrence of positive spillover effects. However, as it is found that even the other sectoral technological variable do not significantly impact on the export performance it means that a pure R\&D exploiting motivation does not have a significant impact as well. With regard to interactions between $\mathrm{R} \& \mathrm{D}$ and resource seeking and export platform FDI, that are proxies of the asset seeking motivations, it is possible to notice that, as expected, the effect is not relevant and the value of the coefficient is even negative. The reason is that asset seeking motivations, as found even in Driffield and Love (2007), do not have enough to offer to affect the host countries. Their aim, instead, is that of having access to technological resources that can be found in that specific country. The results relative to the second proxy used to measure asset seeking motivations (skills), confirm the effects found for R\&D interaction with the exception that the variable is strongly and negatively significant in the case of export platform FDI, proving that skills play a major role in grasping local available knowledge. It may also reflect that this FDI motivation may even contribute to draw skilled labour from the local labour market diminishing in this way the skill content of the domestic exports. This effect is different from the one caused by resource seeking FDI as the coefficient is not significant. Instead, when the variable is interacted with the market seeking FDI proxy, the coefficient is positive and significant proving that MNE's employees, endowed with higher skills, significantly affect the export intensity of the domestic sector even though the export orientation

\footnotetext{
15 When the Hansen test rejects at more than $1 \%$ level of significant the validity of instruments, we further lagged instruments by one period. It happens when market seeking FDI and export platform FDI are interacted with R\&D.
} 


\begin{tabular}{|c|c|c|c|c|c|c|}
\hline & (1) & (2) & (3) & (4) & (5) & (6) \\
\hline xprod & $\begin{array}{l}0.93726^{* * *} \\
(0.05676)\end{array}$ & $\begin{array}{l}0.98565^{* * *} \\
(0.09075)\end{array}$ & $\begin{array}{l}1.00738^{* * *} \\
(0.07388)\end{array}$ & $\begin{array}{l}0.92919 * * * \\
(0.12361)\end{array}$ & $\begin{array}{l}0.94882^{* * *} \\
(0.05519)\end{array}$ & $\begin{array}{l}1.14907 * * * \\
(0.13384)\end{array}$ \\
\hline mseek*rd $^{*}$ & $\begin{array}{l}-1.31378^{*} \\
(0.78058)\end{array}$ & & & & & \\
\hline mseek*skills & & $\begin{array}{l}\text { 48.14494*** } \\
(15.19896)\end{array}$ & & & & \\
\hline rseek $^{*}$ rd & & & $\begin{array}{l}-1.40844 \\
(1.17177)\end{array}$ & & & \\
\hline rseek*skills & & & & $\begin{array}{l}-76.75854 \\
(57.47726)\end{array}$ & & \\
\hline expplat*rd & & & & & $\begin{array}{l}-1.05763 \\
(1.24544)\end{array}$ & \\
\hline expplat*skills & & & & & & $\begin{array}{l}-58.45601 * * * \\
(18.07542)\end{array}$ \\
\hline INVINT & $\begin{array}{l}-0.11149 \\
(0.09429)\end{array}$ & $\begin{array}{l}0.05125 \\
(0.12727)\end{array}$ & $\begin{array}{l}-0.05124 \\
(0.05271)\end{array}$ & $\begin{array}{l}-0.22686 \\
(0.24528)\end{array}$ & $\begin{array}{l}-0.04826 \\
(0.08878)\end{array}$ & $\begin{array}{l}0.06363 \\
(0.14106)\end{array}$ \\
\hline RDPROD & $\begin{array}{l}0.60360^{*} \\
(0.36408)\end{array}$ & $\begin{array}{l}-0.45066 \\
(0.30299)\end{array}$ & $\begin{array}{l}-0.06466 \\
(0.13220)\end{array}$ & $\begin{array}{l}-0.79857 \\
(0.65736)\end{array}$ & $\begin{array}{l}0.50484 \\
(0.55041)\end{array}$ & $\begin{array}{l}0.18108 \\
(0.44211)\end{array}$ \\
\hline LABEMP & $\begin{array}{l}0.03679 \\
(0.02560)\end{array}$ & $\begin{array}{l}-0.08777 * * * \\
(0.03042)\end{array}$ & $\begin{array}{l}0.00788 \\
(0.01351)\end{array}$ & $\begin{array}{l}-0.03007 \\
(0.04210)\end{array}$ & $\begin{array}{l}0.01804 \\
(0.02882)\end{array}$ & $\begin{array}{l}0.09402^{*} \\
(0.05526)\end{array}$ \\
\hline LPDTY & $\begin{array}{l}-0.10510^{* * *} \\
(0.03773)\end{array}$ & $\begin{array}{l}-0.20998^{* *} \\
(0.08583)\end{array}$ & $\begin{array}{l}-0.06622^{* *} \\
(0.02988)\end{array}$ & $\begin{array}{l}-0.12074 \\
(0.09013)\end{array}$ & $\begin{array}{l}-0.11779 * * \\
(0.04746)\end{array}$ & $\begin{array}{l}-0.08733 \\
(0.07474)\end{array}$ \\
\hline EMPSH & $\begin{array}{l}-0.97877 \\
(0.74271)\end{array}$ & $\begin{array}{l}-3.63600 * * \\
(1.67656)\end{array}$ & $\begin{array}{l}-1.30658 \\
(0.86092)\end{array}$ & $\begin{array}{l}-4.76639 \\
(3.81961)\end{array}$ & $\begin{array}{l}-0.40350 \\
(0.81553)\end{array}$ & $\begin{array}{l}4.30206 \\
(2.84837)\end{array}$ \\
\hline $\mathrm{XSH}$ & $\begin{array}{l}0.20227 * \\
(0.11687)\end{array}$ & $\begin{array}{l}0.50473 * * \\
(0.20949)\end{array}$ & $\begin{array}{l}0.18144 \\
(0.15719)\end{array}$ & $\begin{array}{l}0.51616 \\
(0.60974)\end{array}$ & $\begin{array}{l}0.15837 \\
(0.10879)\end{array}$ & $\begin{array}{l}-0.21356 \\
(0.39117)\end{array}$ \\
\hline Year dummies & Yes & Yes & Yes & Yes & Yes & Yes \\
\hline Obs. & 212 & 238 & 212 & 238 & 212 & 238 \\
\hline Wald test & 2730.63 & 518.69 & 4953.50 & 3915.19 & 2351.62 & 870.43 \\
\hline AR1 & $-3.07 * * *$ & $-3.18^{* * *}$ & $-3.03 * * *$ & $-3.05^{* * *}$ & $-3.04 * * *$ & $-2.97 * * *$ \\
\hline AR2 & -1.20 & -1.06 & -1.24 & -0.88 & -1.15 & -0.91 \\
\hline Hansen test & 6.12 & 3.72 & 6.98 & 4.51 & 5.74 & 6.05 \\
\hline
\end{tabular}

of this type of FDI is not relevant. This further result confirms that the technological content of receiving countries' exports comes mainly from a higher worker's skills rather than a purely technological content. As a matter of fact, among the sectoral level variables that should contribute to explain the export performance, we notice that while the labour productivity is usually negatively correlated with the dependent variable, the variable measuring skills is mainly positive or non significant (even though with positive signs). It is useful to note that this variable strongly negatively affects export performance only when it is considered the variable of FDI market seeking interacted with skills that instead strongly positively affects it. We think it is important to stress this result, because it means that domestic and foreign skills are complementary. As a proof, we recognize that for export platform FDI that strongly negatively affect export intensity, the variable of domestic skills is positive and significant $(10 \%)$. 
With respect to the specification involving the measurement of more production oriented activities such as value added and capital expenditures we observe that the Hansen test reports not significant results as before. However, in two cases, that is when market seeking and resource seeking FDI are interacted with value added, the Hansen test rejects the validity of instrument at $1 \%$ level of significance $^{16}$. However, as the test is always rejected at $5 \%$ level of significance we find these sys-GMM estimates reliable as in the previous specifications. We also notice that in some cases a weak significance for test of second order serial correlation is found. As far as the variable of added value is concerned, market seeking FDI results show a positive and significant effect on export intensity: it proves that more embedded MNEs are more willing to share their knowledge with the host domestic sector and that being more embedded inside the local context decreases, to a certain extent, the competition effect. It also means that it is not needed for FDI to be more export oriented to foster export performance but instead, it is more important for them to establish linkages with the host economy to encourage the process of technology transfer. Instead, as expected, for both resource seeking and export platform FDI the effect is not relevant. In particular for resources seeking FDI the result confirms that, even though in this case we are trying to measure the effect from an asset exploiting motivations it means that, contrary to what may happen in developing countries, the local labour demand is not affected by those types of FDI because of the skills' mismatch between MNEs and local firms.

The variable measuring competition deserves a special attention. First of all, it does not demonstrate completely that competition does not act through market stealing effect: this effect should not be relevant in the case of OECD countries whose firms should be able to survive to competition effect. Actually, the coefficient is not significant even though with a negative sign. As a matter of fact, through this channel we can distinguish the impacts of asset seeking motivations coming from the higher embeddedness from those that may cause an improvement in productivity. Indeed, the result found for competition channel indicates that market seeking FDI cause a favourable export spillover effect not by spurring productivity due to the stimulus caused by higher competition but through the influence on local skills and because of technology transfer due to higher embeddedness. In the case of resource seeking FDI, as expected, a positive effect is detected: it suggests that the final effect on export intensity may be first mediated by an improvement in productivity coming from higher local labour demand that, however, is not due to the higher embeddness of subsidiaries. Instead, it comes from the higher competition they establish in the host country. This same level of competition is not established by export platform FDI that being interested in the exploiting domestic markets of neighbouring countries leave the local competition unchanged.

\footnotetext{
${ }^{16}$ As far as market seeking FDI the instruments have been lagged by a further period as with just one lag the validity of instruments is rejected at $5 \%$ level of significance.
} 


\begin{tabular}{|c|c|c|c|c|c|c|}
\hline & (1) & (2) & (3) & (4) & (5) & (6) \\
\hline xprod & $\begin{array}{l}0.92592^{* * *} \\
(0.13286)\end{array}$ & $\begin{array}{l}0.94022^{* * *} \\
(0.05905)\end{array}$ & $\begin{array}{l}0.96679 * * * \\
(0.05544)\end{array}$ & $\begin{array}{l}1.00109 * * * \\
(0.06772)\end{array}$ & $\begin{array}{l}0.96753^{* * *} \\
(0.06222)\end{array}$ & $\begin{array}{l}0.94745^{* * *} \\
(0.06660)\end{array}$ \\
\hline mseek*vad $^{*}$ & $\begin{array}{l}0.36285^{* * *} \\
(0.12677)\end{array}$ & & & & & \\
\hline mseek*cap $^{*}$ & & $\begin{array}{l}-1.03038 \\
(0.69084)\end{array}$ & & & & \\
\hline rseek $^{*}$ vad & & & $\begin{array}{l}-0.04823 \\
(0.03524)\end{array}$ & & & \\
\hline rseek*ap $^{*}$ & & & & $\begin{array}{l}0.73040^{*} \\
(0.42894)\end{array}$ & & \\
\hline expplat*vad & & & & & $\begin{array}{l}-0.21745 \\
(0.18944)\end{array}$ & \\
\hline expplat*cap & & & & & & $\begin{array}{l}-0.82193 \\
(1.10088)\end{array}$ \\
\hline INVINT & $\begin{array}{l}0.27225 \\
(0.18383)\end{array}$ & $\begin{array}{l}-0.12423 \\
(0.11057)\end{array}$ & $\begin{array}{c}-0.05835 \\
(0.10069)\end{array}$ & $\begin{array}{l}0.03580 \\
(0.13960)\end{array}$ & $\begin{array}{l}-0.11218 \\
(0.12297)\end{array}$ & $\begin{array}{l}-0.06108 \\
(0.09294)\end{array}$ \\
\hline RDPROD & $\begin{array}{l}-0.45150 \\
(0.47927)\end{array}$ & $\begin{array}{l}0.36344 \\
(0.34710)\end{array}$ & $\begin{array}{l}-0.07398 \\
(0.17576)\end{array}$ & $\begin{array}{l}0.23036 \\
(0.29785)\end{array}$ & $\begin{array}{l}0.39806 \\
(0.44600)\end{array}$ & $\begin{array}{l}0.37058 \\
(0.52167)\end{array}$ \\
\hline LABEMP & $\begin{array}{l}-0.09481^{* *} \\
(0.04388)\end{array}$ & $\begin{array}{l}0.05486 \\
(0.03634)\end{array}$ & $\begin{array}{l}0.02034 \\
(0.01907)\end{array}$ & $\begin{array}{l}0.02236 \\
(0.01648)\end{array}$ & $\begin{array}{l}0.05947 \\
(0.05096)\end{array}$ & $\begin{array}{l}0.03862 \\
(0.04300)\end{array}$ \\
\hline LPDTY & $\begin{array}{l}-0.14082 * \\
(0.07752)\end{array}$ & $\begin{array}{l}-0.06665 \\
(0.04579)\end{array}$ & $\begin{array}{l}-0.05303^{*} \\
(0.03131)\end{array}$ & $\begin{array}{l}-0.02318 \\
(0.04273)\end{array}$ & $\begin{array}{l}-0.04046 \\
(0.03757)\end{array}$ & $\begin{array}{l}-0.06474 \\
(0.04240)\end{array}$ \\
\hline EMPSH & $\begin{array}{l}-2.25206 \\
(2.42748)\end{array}$ & $\begin{array}{l}-2.04437 \\
(1.28616)\end{array}$ & $\begin{array}{l}-1.25880 \\
(0.96055)\end{array}$ & $\begin{array}{l}0.58021 \\
(1.94924)\end{array}$ & $\begin{array}{l}0.43378 \\
(1.56509)\end{array}$ & $\begin{array}{l}-0.80921 \\
(1.17887)\end{array}$ \\
\hline $\mathrm{XSH}$ & $\begin{array}{l}-0.00848 \\
(0.27204)\end{array}$ & $\begin{array}{l}0.24523 \\
(0.17332)\end{array}$ & $\begin{array}{l}0.14191 \\
(0.13328)\end{array}$ & $\begin{array}{l}-0.17219 \\
(0.33357)\end{array}$ & $\begin{array}{l}0.11886 \\
(0.15455)\end{array}$ & $\begin{array}{l}0.14639 \\
(0.14768)\end{array}$ \\
\hline Year dummies & Yes & Yes & Yes & Yes & Yes & Yes \\
\hline Obs. & 188 & 185 & 188 & 185 & 188 & 185 \\
\hline Wald test & 550.75 & 1977.54 & 3037.21 & 1776.40 & 4824.00 & 2251.59 \\
\hline AR1 & $-1.84 *$ & $-1.93 * *$ & $-2.50 * *$ & $-2.56^{* *}$ & $-2.52 * *$ & $-2.21 * *$ \\
\hline AR2 & $-1.76^{*}$ & -0.68 & $-1.73^{*}$ & $-1.73^{*}$ & $-1.77^{*}$ & -1.57 \\
\hline Hansen test & $8.08^{*}$ & 5.58 & $8.47 *$ & 7.61 & 6.84 & 6.60 \\
\hline
\end{tabular}

Notes: xprod is lagged one year

Robust standard errors in parentheses

* significant at 10\%; ** significant at 5\%; *** significant at 1\%

In the end, we need to examine what happens when a higher level of linkages is established with the parent company (Table 5). As a matter of fact, the way followed to measure the effect is that of considering the level of imports from the headquarters, even though it is not possible to see what is the technological content of the imports. The results find a positive but weakly significant effect only for market seeking FDI, while the coefficient is not significant as far as the other two motivations are concerned even though the coefficients display a positive sign. This fact stimulates two comments: the first is that, even though subsidiaries are now considered to act more independently from the parent company drawing their spillover potential from the linkages with the local context, the linkage with the parent company is nevertheless important for the overall effect they are going to produce. The second is that it is important to consider how the FDI motivation and the flow of resources coming from the parent company interact, as the same amount of resources may give rise to different effects according 
to the motivation under consideration. Especially, in the case of market seeking FDI, the positive effect displayed by the coefficient indicates that foreign subsidiaries that aim to exploit local market besides being more embedded into the local context, also need to be supported from resources coming from the home country to carry out their local activities.

Table 5. Regression result for the model with parent company linkage interaction

(1)

\begin{tabular}{|c|c|c|c|}
\hline xprod & $\begin{array}{l}1.06421 \text { *** } \\
(0.09640)\end{array}$ & $\begin{array}{l}0.98640 * * * \\
(0.07482)\end{array}$ & $\begin{array}{l}0.90878^{* * *} \\
(0.07845)\end{array}$ \\
\hline mseek*impusp & $\begin{array}{l}0.28256^{*} \\
(0.16086)\end{array}$ & & \\
\hline rseek*impusp & & $\begin{array}{l}0.03455 \\
(0.02374)\end{array}$ & \\
\hline expplat*impusp & & & $\begin{array}{l}0.23041 \\
(0.44353)\end{array}$ \\
\hline INVINT & $\begin{array}{l}0.24564^{*} \\
(0.14679)\end{array}$ & $\begin{array}{l}0.06842 \\
(0.08163)\end{array}$ & $\begin{array}{l}0.05052 \\
(0.10402)\end{array}$ \\
\hline RDPROD & $\begin{array}{l}0.53133 \\
(0.46276)\end{array}$ & $\begin{array}{l}0.05108 \\
(0.16558)\end{array}$ & $\begin{array}{l}-0.10995 \\
(0.24129)\end{array}$ \\
\hline LABEMP & $\begin{array}{l}0.01328 \\
(0.02763)\end{array}$ & $\begin{array}{l}0.00466 \\
(0.01720)\end{array}$ & $\begin{array}{l}-0.00668 \\
(0.02758)\end{array}$ \\
\hline LPDTY & $\begin{array}{l}-0.02214 \\
(0.05964)\end{array}$ & $\begin{array}{c}-0.06443^{*} \\
(0.03391)\end{array}$ & $\begin{array}{l}-0.09907 * * \\
(0.03976)\end{array}$ \\
\hline EMPSH & $\begin{array}{l}2.69504 \\
(2.41150)\end{array}$ & $\begin{array}{c}-0.26554 \\
(0.83020)\end{array}$ & $\begin{array}{l}-1.59181^{* *} \\
(0.78096)\end{array}$ \\
\hline $\mathrm{XSH}$ & $\begin{array}{l}-0.51109 \\
(0.42704)\end{array}$ & $\begin{array}{l}-0.05885 \\
(0.17352)\end{array}$ & $\begin{array}{l}0.12696 \\
(0.12953)\end{array}$ \\
\hline Year dummies & Yes & Yes & Yes \\
\hline Obs. & 231 & 231 & 231 \\
\hline Wald test & 5515.50 & 3559.56 & 2383.19 \\
\hline AR1 & $-3.32 * * *$ & $-3.20 * * *$ & $-3.53 * * *$ \\
\hline AR2 & -1.59 & -1.52 & -1.53 \\
\hline Hansen test & 6.74 & 7.23 & 7.21 \\
\hline
\end{tabular}

Notes: xprod is lagged one year

Robust standard errors in parentheses

* significant at 10\%; ** significant at 5\%; *** significant at 1\%
(3)

$$
0.23041
$$

$(0.10402)$

$-0.10995$

$(0.02758)$

$-0.09907 * *$

(0.78096)

0.12696

(0.12953)

2383.19

$-1.53$ 
played by FDI heterogeneity has been largely neglected in the empirical applications and it is not possible to generalize results as studies focused on just one country have been produced so far. The aim of our contribution is that of merging the literature about the FDI export spillover effect with the literature, still scarce, addressing the impact of FDI motivation on receiving countries. By starting from the theoretical framework put forward by Dunning (1993), we make an attempt to further disentangling the channels through which the effect is conveyed in this way accounting for both asset seeking and asset exploiting motivations. In this regard, by using a dataset that provides the final destination of sales of US MNEs over the period 1990-2001, it is investigated the impact of different FDI motivations on sectoral exports of 16 OECD countries.

Our results point to some interesting conclusions: the first is that we confirm that it is not possible to consider FDI as a homogenous external factor without taking into consideration MNEs heterogeneity. As a matter of fact, none of the MNE's foreign subsidiaries display the same spillover potential. In particular, it is possible to recognize that market seeking FDI are those that convey to a greater extent the export spillover effect. This fact is quite counterintuitive, as it is expected that resource seeking and export platform FDI should cause a higher spillover effect as they are more export oriented. The greater effect coming from market seeking FDI is recognized for all channels, except for competition for which we found a non significant result. However, this is a proof of the fact that greater export orientation on the side of MNEs is not relevant in enhancing export intensity of the domestic sectors, as they are already part of worldwide trade network and they do not need to be helped in lowering the sunk costs. The second important result is that when asset seeking motivations are considered, no significant results are found. This contributes to explain how foreign subsidiaries that are inside the host country with the purpose of having access to further technological knowledge have less to offer to the local context, especially in the case of developed countries. In the end, the further way to account for MNEs heterogeneity is that of taking into account the linkage subsidiaries have with mother house. We acknowledge that, actually, the role played by this variable is not particularly relevant for all FDI motivations even though a mild positive effect is found for market seeking motivations.

From a policy perspective, the results obtained are undoubtedly full of implications. Firstly, they encourage to think that not all FDI are of the same kind and because of this fact, economic incentives need to be carefully designed. Secondly, it is important to understand what are the expected outcomes MNEs are going to produce. As a matter of fact, MNEs may produce different outcomes depending not only on the motivation for which they invest in the host country but also on the channel through which they may affect the economy. As a matter of fact, it is not the same if MNEs with higher R\&D potential or more skills intensive are attracted. For this reason, it is not enough to take into 
consideration the motivation by which FDI are attracted in a country but also a proper disentanglement of the effect of each channel is needed in order to clarify the effect they are going to produce.

\section{References}

Aitken, B., Hanson, G.H. and Harrison, A.E. (1997) Spillovers, foreign investment and export behaviour, Journal of International Economics, 43, 103-132

Alfaro, L.A., Chanda, A., Kalmli-Ozcan, S. and Sayek, S. (2004) FDI and economic growth: the role of local financial markets, Journal of International Economics, 64, 89-112.

Arellano, M. and Bond, S. (1991) Some tests of specification for panel data: Monte Carlo evidence and an application to employment equations, Review of Economic Studies, 58, 277-297

Arellano, M. and Bover, O. (1995) Another look at the instrumental-variable estimation of errorcomponents models, Journal of Econometrics, 68, 29-51.

Bende-Nabende, A., Ford, J., Santoso, B. and Sen, S. (2003). The interaction between FDI, output and the spillover variables: Co-integration and VAR analyses for APEC, 1965-99. Applied Economics Letters, 10, 165-172.

Beugelsdijk S., Smeets, R. and Zwinkles, R. (2008) The impact of horizontal and vertical FDI on host's country economic growth, International Business Review, 17, 452-472

Bitzer, J., Geishecker, I. and Görg, H. (2008) Productivity spillovers through vertical linkages: evidence from 17 OECD countries, Economic Letters, 99, 328-331

Blomström, M. and Kokko, A. (1998), Multinational Corporations and Spillovers, Journal of Economic Surveys, 12, 247-277

Blundell, R. and Bond, S. (1999), GMM estimation with persistent panel data: an application to production functions, Institute for Fiscal Studies, Working Paper n.99/04, London

Borensztein, E., De Gregorio, J. and Lee, J-W. (1998) How does Foreign Direct Investment affect economic growth? Journal of International Economics, 45, 115-135.

Cantwell, J. and Mudambi, R. (2005) MNEs competence creating subsidiaries mandates, Strategic Management Journal, 12, 155-172

Castellani, D. and Zanfei, A. (2007) Multinational companies and productivity spillovers: is there a specification error?, Applied Economic Letters, 14, 1047-1051

Damijan J.P., Knell, M., Majcen, B. and Rojec, M. (2003) Technology Transfer through FDI in Top10 Transition Countries: How Important are Direct Effects, Horizontal and Vertical Spillovers? William Davidson Institute, WP n. 549

Driffield, N. and Love, J. (2007) Linking FDI motivation and host economy productivity effects: conceptual and empirical analysis, Journal of International Business Studies, 38, 460-473. 
Dunning, J. H. (1977), Trade, Location of Economic Activity and the Multinational Enterprise: a search for an eclectic approach, London, Macmillan

Dunning, J.H. (1979) Explaining changing patterns of international production: in defence of an eclectic theory, Oxford Bulletin of Economics and Statistics, 41, 269-95

Dunning, J. H. (1993) Multinational Enterprises and the Global Economy, Wokingham: Addison-Wesley

Duttaray, M., Dutt, A. and Mukhopadhyay, K. (2008) Foreign direct investment and economic growth in less developed countries: empirical study of causality and mechanisms, Applied Economics, 40, 19271939

Ekholm, K., Forslid, R. and Markusen, J. (2007) Export Platform Foreign Direct Investment, Journal of the European Economic Association, 5, 776-95.

Fosfuri, A. and Motta, M. (1999) Multinational without advantages, Scandinavian Journal of Economics, 101, 617-630

Görg, H. and Strobl, E. (2001) Multinational Companies and Productivity Spillovers: a meta-analysis Economic Journal, 111, F723-F739.

Greenaway, D., Sousa N. and Wakelin, K. (2004) Do domestic firms learn to export from multinationals? European Journal of Political Economy, 20, 1027-1043

Grossman, G. M., Helpman, E. and Szeidl A. (2006) Optimal integration strategies for the multinational firm, Journal of International Economics, 70, 216-238

Hanson, G.H., Mataloni, R.J. and Slaughter, M. J. (2005) Vertical production networks in multinational firms, The Review of Economics and Statistics, 87, 664-678

Heckman, J. (1979) Sample Selection Bias as a Specification Error, Econometrica, 47, 153-161.

Hedge, D. and Hicks, D. (2008) The maturation of global corporate R\&D: evidence from the activity of U.S. foreign subsidiaries, Research Policy, 37, 390-406

Helpman, E. (1984) A simple theory of international trade with multinational corporations, Journal of Political Economy, 92, 451- 471.

Helpman, E., Melitz, M. and Yeaple, S. (2004) Export Versus FDI with Heterogeneous Firms, American Economic Review, 94, 300-316

Herzer, D., Klasen, S. and Nowak-Lehmann, F. (2008) In search of FDI-led growth in developing countries: the way forward, Economic Modelling, 25, 793-810

Holm, U., Malmberg, A., and Solvell, O. (2003) Subsidiary impact on host country economies-the case of foreign owned subsidiaries attracting investment into Sweden, Journal of Economic Geography, 3, $389-408$

Javorcik, B. S. (2004) Does foreign direct investment increase the productivity of domestic firms? In search of spillovers through backward linkages, American Economic Review, 94, 605-27 
Kneller, R. and Pisu, M. (2007) Industrial linkages and export spillover from FDI, World Economy, 30, 105-134

Kokko, A. (1994) Technology, market characteristics and spillovers, Journal of Development Economics, 43, 279-293

Kokko A., Zejan, M. and Tansini, R. (2001) Trade regimes and spillover effects from FDI: evidence from Uruguay, Weltwirtschaftliches Archiv, 137, 124-149

Kuemmerle, W. (1999) The drivers of foreign direct investments into research and development: an empirical investigation, Journal of International Business Strategy, 30, 1-24.

Kugler, M. (2006) Spillover from FDI: within or between Industries?, Journal of Development Economics, 80,444-477

Kumar, N. (2001) Determinants of location of overseas R\&D activities of multinational enterprises: the case of US and Japanese corporations, Research Policy, 30, 159-174

Lall, S. (1980) Vertical interfirm linkages in LDCs: an empirical study, Oxford Bullettin of Economic Statistics, 42, 203-226

Le Bas, C. and Sierra, C. (2002) Location versus home country advantages in R\&D activities: some further results on Multinationals' location strategies, Research Policy, 31, 589-609

Li, X. and Liu, X. (2005) Foreign Direct Investment and economic growth: an increasingly endogenous relationship, World Development, 33, 393-407

Lipsey, R. E. and Sjöholm, F. (2005) The impact of inward FDI on host countries: why such different answers, in Moran, T. H., Graham, E. and Blomström, M. (eds) Does Foreign Direct Investment Promote Development?, Washington: Institute for International Economics

Madariaga, N. and Poncet, S. (2007) FDI in chinese cities: spillovers and impact on growth. World Economy, 30, 837-862.

Marin, A. and Bell, M. (2006) Technology spillovers from foreign direct investment: an exploration of the active role of MNC subsidiaries in the case of Argentina in the 1990s', Journal of Development Studies $42,678-697$

Marin, A. and Sasidharan, S. (2008) The Heterogeneity of MNC' Subsidiaries and Technology Spillovers: Explaining positive and negative effects in emerging economies, UNU-MERIT Working Paper series n.066

Markusen, J.R. (1984) Multinationals, multi-plant economies, and the gains from trade, Journal of International Economics, 16, 205-226.

Markusen, J.R. and Maskus, K. (2002) Discriminating among alternative theories of the multinational enterprise, Review of International Economics, 10, 694-707

Meyer, K. and Sinani, E. (2009) When and where does foreign direct investment generate positive spillovers? A meta-analysis, Journal of International Business Studies, 40, 1075-1094 
Olofsdotter, K. (1998) Foreign direct investment, country capabilities and economic growth, Weltwirtschaftliches Archiv, 134, 534-547

Power, L. (1998) The missing link: technology, investment, and productivity. Review of Economics and Statistics, 80, 300-313.

Roodman, D. (2006) How to do xtabond2: An introduction to "difference" and "system" GMM in Stata, Center for Global Development, Working Paper n.103, Washington DC

Ruane, F. and Sutherland, J. (2005) Foreign Direct Investment and export spillovers: how do export platforms fare?, IIIS Discussion Paper No. 58

Zanfei, A. (2000) Transnational firms and changing organization of innovative activities, Cambridge Journal of Economics, 5, 515-554. 


\section{APPENDIX}

Table A1. Correlation matrix

\begin{tabular}{|c|c|c|c|c|c|c|c|c|c|c|}
\hline & xprod & mseek & rseek & expplat & rdprod & invint & labemp & labproduc & compexp & emptot \\
\hline xprod & 1 & & & & & & & & & \\
\hline mseek & -0.6271 & 1 & & & & & & & & \\
\hline rseek & 0.1401 & -0.2617 & 1 & & & & & & & \\
\hline expplat & 0.4406 & -0.6733 & -0.5373 & 1 & & & & & & \\
\hline rdprod & -0.0093 & 0.1781 & -0.343 & 0.1071 & 1 & & & & & \\
\hline invint & -0.0281 & 0.1356 & -0.3015 & 0.1124 & 0.3453 & 1 & & & & \\
\hline labemp & 0.0478 & 0.1628 & -0.217 & 0.024 & 0.3949 & 0.4984 & 1 & & & \\
\hline labproduc & 0.0691 & 0.1178 & 0.0387 & -0.1326 & -0.1798 & -0.1082 & -0.016 & 1 & & \\
\hline compexp & 0.1778 & -0.2949 & 0.108 & 0.1749 & 0.0869 & 0.2963 & 0.2137 & -0.0417 & 1 & \\
\hline emptot & -0.0167 & -0.2355 & -0.0978 & 0.2806 & 0.0314 & -0.087 & -0.2339 & -0.2186 & 0.4952 & \\
\hline
\end{tabular}

Table A2. Descriptive statistics for sectoral variables (ISIC Rev. 3 classification)

\begin{tabular}{|l|l|l|l|l|l|l|l|l|}
\hline Sectors-ISIC Rev.3 & & xprod & invint & rdprod & labemp & labproduc & compexp & emptot \\
\hline Chemicals and chemical products (24) & Mean & 52.87069 & 18.82286 & 4.188095 & 170.306 & 95.00827 & 10.56596 & 1.065169 \\
\hline & Sd & 30.2335 & 4.800979 & 2.773135 & 24.47607 & 19.99203 & 5.366066 & 0.356728 \\
\hline Machinery and equipment, n.e.c. (29) & Mean & 54.83978 & 10.25132 & 1.96875 & 127.86 & 92.85112 & 9.178723 & 1.818378 \\
\hline & Sd & 24.58353 & 2.656517 & 0.955998 & 12.49585 & 13.89743 & 4.857914 & 0.788427 \\
\hline Transport equipment (34-35) & Mean & 60.41022 & 18.24671 & 2.696471 & 140.4911 & 93.02671 & 13.89787 & 1.587895 \\
\hline & Sd & 26.72956 & 8.093869 & 1.849001 & 21.41923 & 16.88888 & 8.407311 & 0.554549 \\
\hline
\end{tabular}

Table A3. Descriptive statistics for US MNEs variables

\begin{tabular}{|c|c|c|c|c|c|c|c|c|c|}
\hline $\begin{array}{l}\text { Sectors (BEA industry } \\
\text { classification*) }\end{array}$ & & lsales & salesus & fsales & $\mathrm{rd}$ & capexp & impusp & $\mathrm{vad}$ & skills \\
\hline \multirow[t]{2}{*}{ Chemicals } & Mean & 4581.421 & 528.4797 & 3214.858 & 207.76 & 414.0583 & 589.9059 & 2549.2 & 0.583688 \\
\hline & $\mathrm{Sd}$ & 4270.381 & 905.3642 & 3055.767 & 244.1188 & 359.2163 & 736.1416 & 2067.301 & 0.464522 \\
\hline \multirow[t]{2}{*}{ Machinery } & Mean & 3301.045 & 751.6096 & 2808.543 & 75.18452 & 139.7227 & 677.4813 & 1384.389 & 0.486113 \\
\hline & $\mathrm{Sd}$ & 3775.331 & 1137.749 & 3875.76 & 126.328 & 217.0804 & 975.0295 & 1842.662 & 0.187205 \\
\hline \multirow[t]{2}{*}{ Transportation equipment } & Mean & 5576.752 & 3188.669 & 2991.91 & 225.1293 & 402.1565 & 1803.286 & 2086.397 & 0.39162 \\
\hline & $\mathrm{Sd}$ & 7472.409 & 9931.252 & 5399.353 & 498.2161 & 651.5501 & 6043.478 & 3262.222 & 0.125049 \\
\hline
\end{tabular}

Notes: * from 1990-1997 BEA uses the SIC sector classification, while from 1999 onwards NAICS is used.

1sales: local sales; salesus: sales back to United States; fsales: sales to foreign countries other than the host countries

$V$ ariables are expressed in millions of Us dollars, except for skills that is built dividing compensation of employees by the number of employees (thousands) 